\title{
NASA-TM--100.223
}

NASA Technical Memorandum 100223

\section{Small Reactor Power Systems for Manned Planetary Surface Bases}

\author{
Harvey S. Bloomfield \\ Lewis Research Center \\ Cleveland, Ohio
}

This report was prepared as an account of work sponsored by an agency of the United States Government. Neither the United States Government nor any agency thereof, nor any of their employees, makes any warranty, express or implied, or assumes any legal liability or responsibility for the accuracy, completeness, or usefulness of any information, apparatus, product, or process disclosed, or represents that its use would not infringe privately owned rights. Reference herein to any specific commercial product, process, or service by trade name, trademark, manufacturer, or otherwise does not necessarily constitute or imply its endorsement, recommendation, or favoring by the United States Government or any agency thereof. The views and opinions of authors expressed herein do not necessarily state or reflect those of the United States Government or any agency thereof. 


\section{DISCLAIMER}

This report was prepared as an account of work sponsored by an agency of the United States Government. Neither the United States Government nor any agency Thereof, nor any of their employees, makes any warranty, express or implied, or assumes any legal liability or responsibility for the accuracy, completeness, or usefulness of any information, apparatus, product, or process disclosed, or represents that its use would not infringe privately owned rights. Reference herein to any specific commercial product, process, or service by trade name, trademark, manufacturer, or otherwise does not necessarily constitute or imply its endorsement, recommendation, or favoring by the United States Government or any agency thereof. The views and opinions of authors expressed herein do not necessarily state or reflect those of the United States Government or any agency thereof. 


\section{DISCLAIMER}

Portions of this document may be illegible in electronic image products. Images are produced from the best available original document. 
NA.SA-TM-100.223

NASA Technical Memorandum 100223

\title{
Small Reactor Power Systems for Manned Planetary Surface Bases
}

\author{
Harvey S. Bloomfield \\ Lewis Research Center \\ Cleveland, Ohio
}

\section{DISCLAIMER}

\section{December 1987}

\begin{abstract}
This report was prepared as an account of work sponsored by an agency of the United States Government. Neither the United States Government nor any agency thereof, nor any of their employees, makes any warranty, express or implied, or assumes any legal liability or responsibility for the accuracy, completeness, or usefulness of any information, apparatus, product, or process disclosed, or represents that its use would not infringe privately owned rights. Reference herein to any specific commercial product, process, or service by trade name, trademark, manufacturer, or otherwise does not necessarily constitute or imply its endorsement, recommendation, or favoring by the United States Government or any agency thereof. The views and opinions of authors expressed herein do not necessarily state or reflect those of the United States Government or any agency thereof.
\end{abstract}

\section{N/Sก}




\title{
SMALL REACTOR POWER SYSTEMS FOR MANNED PLANETARY SURFACE BASES
}

\author{
Harvey S. Bloomfield \\ National Aeronautics and Space Administration \\ Lewis Research Center \\ Cleveland, Ohio 44135
}

\section{SUMMARY}

A preliminary feasibility study of the potential application of small nuclear reactor space power systems to manned planetary surface base missions has been conducted. The purpose of the study was to identify and assess the technology, performance, and safety issues associated with integration of reactor power systems with an evolutionary manned planetary surface exploration scenario.

The requirements and characteristics of a variety of human-rated modular reactor power system configurations selected for a range of power levels from $25 \mathrm{kWe}$ to hundreds of kilowatts is described. Trade-off analyses for reactor power systems utilizing both man-made and indigenous shielding materials are provided to examine performance, installation, and operational safety feasibility issues.

The results of this study have confirmed the preliminary feasibility of a wide variety of small reactor power plant configurations for growth oriented manned planetary surface exploration missions. The capability for power level growth with increasing manned presence, while maintaining safe radiation levels, was favorably assessed for nominal 25 to 100 kWe modular configurations. No feasibility limitations or technical barriers were identified and the use of both distance (in lieu of shielding) and indigenous planetary soil material for human rated radiation shielding were shown be viable and attractive options.

\section{INTRODUCTION}

A program plan for planetary exploration and exploitation will likely consist of a series of phased elements that provide a scenario for orderly growth that accounts for increasing power requirements as manned presence increases. Table I presents a list of major phased elements leading up to, and including, the establishment of a permanent, sustained surface base. The power requirements and power system technologies available to meet these requirements are discussed below.

Precursor robotic observer and sample return missions will probably utilize the NASA Mariner Mark II type spacecraft. Near term precursor missions using this spacecraft are constrained to chemical propulsion and either RTG's or solar photovoltaic (PV) power supplies at power levels up to about 1 kWe. Far term precursor mission goals could be enhanced by the use of small space reactors providing power levels of $25 \mathrm{kWe}$ and higher for both nuclear electric propulsion (NEP) and science power. A recent NASA study (ref. 1) has shown the preliminary feasibility of small reactor integration with a Mariner Mark II spacecraft to provide power for both science and NEP for the Cassini Mission. 
Investigation of potential outpost sites and initial surface station development may require power levels from $25 \mathrm{kWe}$ to about $100 \mathrm{kWe}$. Potential power supply candidates include solar PV with battery or regenerative fuel cell (RFC) storage, solar dynamic (SD) with phase change material thermal energy or RFC storage or small reactor power systems.

The establishment of a permanent, sustained surface base may require power supplies that can build up to levels in the hundreds to thousands of electrical kilowatts. This growth buildup can be achieved by deployment of modular groupings of small to moderate size nuclear or solar power systems.

The selection of a particular candidate power system for any of the planetary exploration elements discussed is highly dependent upon the power level required and the physical characteristics of the specific planetary surface in question.

For example, a requirement for power levels in the hundreds to thousands of kilowatts on the lunar surface could show very significant system mass advantages for nuclear power systems. This superiority over both solar photovoltaic and solar dynamic systems is due to the extended shade or darkness duration at a typical nonpolar lunar site (about two continuous weeks per month). Similar power level requirements on the Martian surface, for example, will reduce the advantage of nuclear power systems somewhat because of the cyclical nature of the darkness duration, but the reduced Martian surface solar intensity (about 50 percent of that on the moon or earth) will still maintain an important nuclear mass advantage.

An important consideration for any candidate surface power system concept is a definition of requirements. The projected requirements 1 ist shown in table II is generalized for planetary surface power applications and does not include any detailed mission specific design requirements relating to power system lifetime, reliability, mass or volume limitations, etc. The requirement for compatibility with the planetary environment includes interactions of the atmospheric constituents with any high operating temperature material of the power system. This requirement will, for example, probably eliminate any Mars surface power system that utilizes high temperature refractory metal alloy materials in construction. The requirement for surface deployable radiators represents an attempt to limit astronaut construction activities by using the planetary surface as a support for the large radiators needed. The consequence of one-sided heat transfer inherent in this requirement will however, double the heat rejection area needed for typical flat plate space radiators. The requirement for compact/transportable power systems is based on the assumption that they may have to be moved to their sites by a rover vehicle with relatively modest capability for transporting large or heavy loads over long distances. The last requirement, modularity for growth, is based on the rationale that as manned presence increases with time so will power requirements. Thus, the use of replicated or modular power systems could provide significant installation and operational benefits along with the increased reliability that accrues from multiple power supplies.

\section{SMALL REACTOR POWER SYSTEM CHARACTERIZATION}

Over the past 20 years a wide variety of small (in comparison with terrestrial power plants) reactor power system concepts have been proposed and 
advocated for development by U.S. industry. At the present time the SP-100 space reactor power system concept is under active development in the U.S. Although this program is currently focused on a $100 \mathrm{kWe}$ system design and demonstration the concept is capable of providing high performance over an extremely wide range of power levels. Baseline concept designs can provide low specific mass systems down to about $25 \mathrm{kWe}$ and growth versions would be capable of multimegawatt output with high performance Brayton or Stirling cycle energy conversion. There is, however, considerable interest in high performance reactor power systems that can provide power over the 1 to $25 \mathrm{kWe}$ range for the plantary exploration and surface power mission elements identified in table I. In late 1986 the NASA Lewis Research Center solicited current concepts from industry and conducted a preliminary feasibility and safety assessment of small reactor concepts for this low power regime (ref. 1). A summary matrix of the concepts evaluated is shown in table III. Two generic reactor types, pin and solid core, cooled by three heat transport modes to provide thermal energy to a variety of static and dynamic thermal-to-electric power conversion devices were evaluated. The small reactor concepts considered are relatively compact and typical dimensions are shown in figure 1 for a typical $200 \mathrm{kWt}$ reactor design using a pin type core with forced convection cooling. This concept uses a central control rod and radial and axial reflectors for reactivity control. When coupled to a direct or static power conversion subsystem system electrical outputs in the 10 to $15 \mathrm{kWe}$ range are produced.

Coupling to a more efficient dynamic power conversion subsystem would generate electrical power in the 30 to $40 \mathrm{kWe}$ range.

Although relatively compact, the reactor is the major mass component of the unshielded system. This is shown is table IV which represents a typical unshielded mass breakdown of a reactor power system using a thermoelectric ( $T / E$ ) power conversion concept. Output powers over the range of 1 to $25 \mathrm{kWe}$ are based on a conversion subsystem efficiency of 5 percent. Reactor mass estimates are based on a composite model that represents the concepts evaluated in reference 1 , and radiator masses are based on one-sided heat rejection at a temperature of $800 \mathrm{~K}$. Shield mass has been specifically omitted from table IV because shield configurations are strongly dependent on a wide range of factors as shown in table $V$. Even for the specific mission application of planetary surface power many shielding configuration options are possible. These options are shown in figure 2 which schematically depicts the surface reactor power system on the left side of each configuration and the occupied surface base habitat on the right side. The unshielded configuration trades off shield mass at the expense of large reactor-to-base distances which results in a mass penalty for long power transmission line. The shadow shield configuration utilizes man-made shields manufactured on Earth and transported to the planetary surface. The remaining two shield options utilize indigenous surface material either in the form of a built-up mound or an excavation. Not shown, but certainly under consideration, is the utilization of existing surface depressions or craters.

In order to calculate the thickness requirements of these shielding configurations the dose and dose rate guidelines and constraints for safe humanrated radiation exposure must be identified since human rated dose guidelines will always require more radiation attenuation than that required for power system electronics or instruments at the same location. Estimates for total maximum integrated manned dose as a function of exposure time and body location are shown in table VI. The integrated doses shown are for total exposure to both natural (uncontrollable) radiation sources and man-made controllable 
radiation sources. Current preliminary considerations of the NCRP Scientific Committee No. 75 have established a 5 Rem depth dose guideline for controllable radiation sources such as reactor power systems with a 25 Rem total (controllable plus uncontrollable) dose for a 30 day exposure. The NCRP has also suggested that an increase in the 30 day total exposure depth dose from 25 to 50 Rem be allowed for exploratory missions. At the present time however, there is no indication of a corresponding allowable increase in the 5 Rem dose guideline for controllable radiation sources. For the purpose of presenting parametric analyses of shield requirements both 5 Rem and 25 Rem dose guidelines will be used to represent the range of potential allowable depth dose for 30 day astronaut exposure time.

The following sections of this report will describe and evaluate the planetary surface shielding options available and discuss the issues associated with them.

\section{SHADOW SHIELD OPTION}

This shield option utilizes highly efficient shielding materials manufactured and assembled on Earth, integrated with the reactor power system and delivered to the planetary surface.

A top view of a typical shadow shield configuration layout is shown in figure 3. Both the reactor and shield are assumed to be "sitting" on a flat section of planetary surface. The shield, which is located as close as possible to the reactor to minimize shield mass, provides a shielded width at the surface base habitat that is a function of the reactor-to-base distance and the shield half-angle.

Parametric analyses of shield thickness and mass requirements were carried out using an unpublished NASA Lewis computer code based on Monte Carlo analyses. Shadow shield mass as a function of reactor-to-base distance is shown in figure 4 for a $500 \mathrm{kwt}$ reactor thermal output and a $5 \mathrm{~m}$ base habitat height; parameters are shielded width at the base and integrated dose. ( $A$ reactor power system thermal output of $500 \mathrm{kWt}$ will generate about $25 \mathrm{kWe}$ with a direct power conversion subsystem and about $100 \mathrm{kWe}$ with a dynamic or heat engine power conversion subsystem.) A $5 \mathrm{~m}$ base habitat height was selected to represent a two-story structure whose walls were conservatively assumed to have no inherent shielding attenuation capability. At an arbitrary $100 \mathrm{~m}$ reactor-to-base distance the shield mass for a $40 \mathrm{~m}$ width at the base habitat is about $300 \mathrm{~kg}$ for either the $5 \mathrm{Rem} / 30$ day or $25 \mathrm{Rem} / 30$ day dose constraint. For a $160 \mathrm{~m}$ width shield mass estimates range from about 400 to $500 \mathrm{~kg}$ for the same dose constraints at $100 \mathrm{~m}$ distance. (Specification of a required shield width will depend on astronaut activity location and duration.)

A typical shadow shield design and its dimensions are shown in figure 5. The human-rated shield shown for a $500 \mathrm{kWt}$ reactor thermal output consists of the three alternating layers of tungsten $(W)$ at about $5 \mathrm{~cm}$ each, and lithium hydride ( $\mathrm{LiH})$ at thicknesses of 12,11 , and $55 \mathrm{~cm}$ each. 


\section{UNSHIELDED OPTION}

This concept utilizes large reactor-to-base distances in lieu of shielding and is based on the inverse distance-squared radiation attenuation law. As shown in figure 6 , required reactor-to-base distances will vary from about 1 to $5 \mathrm{~km}$ over the relevant dose constraint range. Application of this data to an unshielded reactor powered surface base concept is shown in figure 7 . This figure presents a conceptual layout of a surface base powered by modular reactor power systems, each located in a quadrant around a central habitable base. The distances shown in the figure are based upon the use of $100 \mathrm{kWt}$ reactors if a $5 \mathrm{Rem} / 30$ day dose constraint is required, or $400 \mathrm{kWt}$ reactors if a $25 \mathrm{Rem} / 30$ day dose constraint is used. These reactor thermal power levels correspond to system output power levels of from 5 to $100 \mathrm{kWe}$ per module depending on the type of power conversion method selected.

The modular unshielded surface base concept can, in principle, provide up to megawatt power levels when all four quadrants are occupied by reactor power systems that are added as the base power requirements grow; the concept shown in figure 7 is designed to provide up to $400 \mathrm{kWe}$. A $1 \mathrm{~km}$ wide minimum pathway is provided in four directions to allow safe ingress and egress to and from the base habitat. The $4.4 \mathrm{~km}$ distance shown from the center of the base to each reactor defines the length of each power transmission line needed to supply base electrical power. For a standard two cable design the required total power transmission distance is $8.8 \mathrm{~km}$ for each power system. This represents a mass penalty that varies with bus power, source voltage, percent power loss, and conductor operating temperature. An approach to evaluate these combined effects for dc transmission has been developed at NASA Lewis, and the parametric results are shown in figure 8 . The figure shows the effect of transmission line length, source voltage and operating temperature on the mass requirements for a $25 \mathrm{kWe}$ power source. A 5 percent transmission power loss, 0.50 thermal radiation view factor to space at a sink temperature of $215 \mathrm{~K}$, and a conductor emissivity of 0.8 have been assumed. Conductor diameters varied from about 1.5 to $11 \mathrm{~mm}$ over the parametric ranges considered.

These results clearly indicate the advantage of high dc voltage levels in reducing the transmission cable mass penalty. For the conceptual surface power system layout shown in figure 7 the transmission cable mass penalties for each power system will be less than $100 \mathrm{~kg}$ for bus voltage levels of $5000 \mathrm{~V}$ or more. The mass penalty for a state-of-the-art $25 \mathrm{kWe}$ voltage inverter, which is required to increase power system output voltage levels to the $5000 \mathrm{~V}$ range, will be on the order of $2 \mathrm{~kg} / \mathrm{kWe}$ or about $50 \mathrm{~kg}$.

\section{PLANETARY SURFACE MATERIAL SHIELD OPTION}

This shield configuration option is based upon the use of indigenous planetary surface material to provide radiation attenuation. A composite surface material shielding effectiveness was generated using a combination of lunar and Martian soil data, the MCNP Monte Carlo neutron and photon transport code, and ENDF/B-IV cross section data. Table VII summarizes the effective neutron and gamma ray attenuation coefficient results which were used to generate a plot of required surface material thickness as a function of reactor thermal power. This shown in figure 9 for both the $5 \mathrm{Rem} / 30$ day and $25 \mathrm{Rem} / 30$ day dose constraints and two reactor-to-base distances, zero and $100 \mathrm{~m}$. This distance is actually that from the back or base side of the surface material 
shield to the base boundary. For a $500 \mathrm{kWt}$ reactor thermal power level a surface material shield thickness of about $5 \mathrm{~m}$ will provide a $5 \mathrm{Rem} / 30$ day dose at a reactor-to-base distance of $100 \mathrm{~m}$. Increasing the surface material thickness to $7 \mathrm{~m}$ would allow up to 30 day occupancy immediately adjacent to the shield should it be required.

In addition to the required thickness, the volume and mass of the surface material to be collected is also of interest with respect to the requirements for materials handling equipment. For a $7 \mathrm{~m}$ thick shadow shield that provides a $160 \mathrm{~m}$ width for a $5 \mathrm{~m}$ high base habitat at a reactor-to-base distance of $100 \mathrm{~m}$ the suraface material volume that must be collected is on the order of $16 \mathrm{~m}^{3}$ with a mass of about $2 \times 10^{4} \mathrm{~kg}$. This rather small volume and mass should be within the capability of modest material handling equipment that should be normally avallable for other planetary surface base construction operations.

\section{SURFACE EXCAVATION SHIELD OPTION}

The placement of reactor power systems within manmade excavations or existing small surface craters may be the simplest means of providing personnel shielding for planetary surface power installations. In order to minimize astronaut activity excavation volumes should be as small as possible. This can be accomplished by placing either the reactor subsystem alone or the reactor plus energy conversion subsystem inside the excavation. This choice will depend on the required level of integration of the reactor and power conversion subsystems. In either case, however, both the radiation sensitive power processing equipment and the large surface area radiator would be located outside the excavation and on the planetary surface. Excavation volume requirements for these compact systems will be minimal; hole depths of $1 \mathrm{~m}$ and diameters of less than $2 \mathrm{~m}$ should be ample for power systems capable of generating up to $100 \mathrm{kWe}$.

Locating suitable craters equivalent to manmade excavations may prove to be difficult since crater depth, diameter and location requirements are important. However, many larger craters that can accommodate a complete reactor power system including radiator and power processor exist on the Lunar and Martian surface. Local instrument rated spot shielding, however, may be required if radiation sensitive power processing equipment must be located near the unshielded reactor.

\section{SURFACE MATERIAL ACTIVATION}

An evaluation of planetary surface material activation due to transmutation by reactor neutron capture was conducted to assess its importance. Surface soil material activation will produce secondary gamma ray sources in soil material exposed to neutrons leaking from an unshielded reactor. In general, activation will be of more concern for unshielded reactors located in excavations since this geometry exposes the most surface material close to reactor neutron radiation.

The soil material activation analysis was based on the Viking landing site soil composition data shown table VIII. The ORIGEN computer code was used to calculate activation inventories and energy rates as a function of 
time after shutdown following ten year operation. The bare reactor source (70 by $100 \mathrm{~cm}$ long) was assumed to be located in a $100 \mathrm{~cm}$ deep excavation and surrounded by a soil cylinder; the thickness of activated soil was assumed to be $500 \mathrm{~cm}$. The results of the activation calculations are shown in tables IX and $X$.

Table IX shows the time growth inventory of actvated soil material in Curies for each of the important radionuclide species. Maximum inventory builds quickly for about the first 10 years and at 80 years after shutdown activity is negligible.

Table $X$ relates the ORIGEN results in terms of human radiation exposure. Three photon energies were found to represent the majority of the secondary gamma ray production with energy rates that are relatively constant over the first 10 years after reactor shutdown. Surface activation dose rates $1 \mathrm{~m}$ from the reactor excavation are only about $20 \mathrm{~m} R E M / h r$ and at $2 \mathrm{~m}$ are negligible. These surface dose rate calculations were based on the conservative assumption that all of the soil activation photons were collapsed into a point source located in the center of the excavation.

The 30 day exposure dose results shown in table $X$ are also presented for the planetary surface material shield option case discussed previously. These results show that an astronaut can safely spend 30 days or more at the back surface of the required $5 \mathrm{~m}$ shield.

These results indicate that planetary soil activation is insignificant in terms of human exposure. However, a word of caution regarding the soll composition data shown in table VIII is in order. The accuracy and completeness of this data is unknown and therefore there is a possibility of undetected trace elements and isotopes that could produce energetic photons. Precursor science and sample return missions will be required to determine detailed surface material compositions to low ppm levels.

\section{ACKNOWLEDGEMENTS}

The author wishes to acknowledge the significant contributions of the following individuals: B. McKissock, NASA Lewis Research Center, who provided innovative shielding code development to accomodate specialized geometries required for planetary surface deployment; $A$. Klein, NASA-ASEE Summer Faculty Fellow, who provided planetary soil neutron and gamma ray attenuation and thickness results; S. Voss, Los Alamos National Laboratory, who provided planetary soil activation analysis results; G. Schwarze, NASA Lewis Research Center, who provided the development and implementation of a new computational procedure to analyze planetary surface transmission cable performance.

\section{REFERENCE}

1. Bloomfield, H.S., "Small Space Reactor Power Systems for Unmanned Solar System Exploration Missions," NASA TM-100228, 1987. 
TABLE I. - ELEMENTS OF A PHASED

PLANETARY EXPLORATION PROGRAM

Precursor robotic observer/sample return missions

Manned investigation of potential outpost sites

Initial development of surface outpost/station

Establishment of permanent/sustained surface base

TABLE II. - PRELIMINARY LIST OF

REQUIREMENTS FOR SURFACE

POWER SYSTEMS

Compatibility with environment

Surface - deployable radiator

Compact/transportable to site

Modular for growth

TABLE III. - MATRIX OF SMALL REACTOR POWER

SYSTEM CONCEPTS

\begin{tabular}{|l|c|c|}
\hline Reactor & Heat Transport & Power Conversion \\
\hline Pin type & Convective & T/E, BC, SC, ORC \\
\cline { 2 - 3 } & Heat pipe & T/E, T/I, SC \\
\hline Solid core & Conductive & T/I \\
\cline { 2 - 3 } & Heat pipe & AMTEC \\
\cline { 2 - 3 } & Radiative & T/E \\
\hline
\end{tabular}

${ }^{\mathrm{a} T / E}$ - Thermoelectric

T/I - Thermionic

AMTEC - Alkali metal thermoelectric convertor

BC - Brayton cycle

SC - Stirling cycle

ORC - Organic Rankine cycle 
TABLE IV. - UNSHIELDED REACTOR POWER SYSTEM

SYSTEM MASS BREAKDOWN, $\mathrm{kg}$

\begin{tabular}{|l|r|r|r|r|}
\hline \multicolumn{1}{|c|}{ Subsystem } & \multicolumn{4}{|c|}{ Output power, kWe } \\
\hline & 1 & 5 & 10 & 25 \\
\hline Reactor & 220 & 260 & 320 & 530 \\
Heat Transport & 19 & 52 & 66 & 120 \\
T/E conversion & 3 & 17 & 33 & 83 \\
Power conditioning & 15 & 40 & 62 & 118 \\
Radiator & 5 & 24 & 47 & 168 \\
Structure and I/F & 22 & 57 & 75 & 115 \\
\hline Total & 289 & 473 & 650 & 1201 \\
\hline
\end{tabular}

TABLE V. - REACTOR SHIELDING REQUIREMENTS

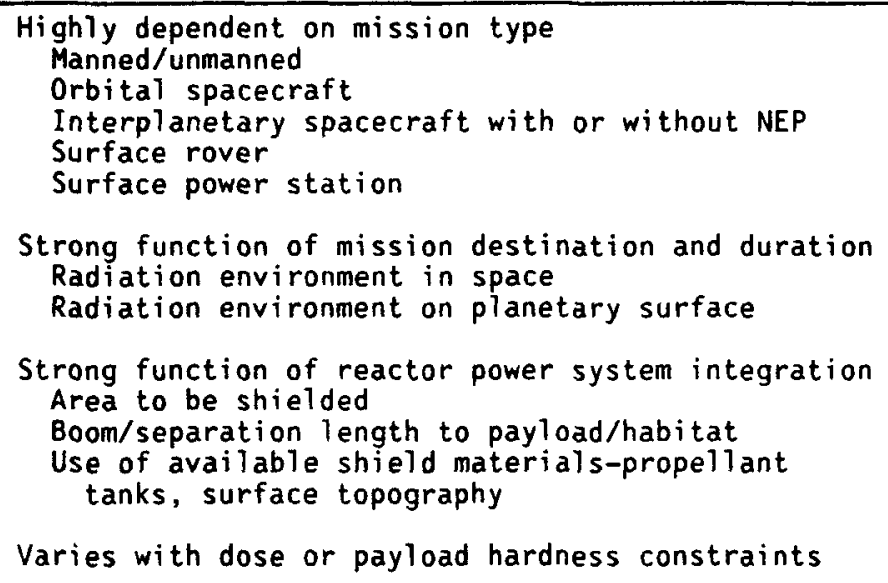

Strong function of mission destination and duration Radiation environment in space

Radiation environment on planetary surface

Strong function of reactor power system integration Area to be shielded

Boom/separation length to payload/habitat Use of available shield materials-propellant tanks, surface topography

Varies with dose or payload hardness constraints

TABLE VI. - TOTAL INTEGRATED MANNED DOSE CONSTRAINTS ${ }^{a}$

[Exposure limit (REM).] ${ }^{b}$

\begin{tabular}{|l|c|c|c|}
\hline Exposure time & $\begin{array}{c}\text { Depth, } \\
5 \mathrm{~cm}\end{array}$ & $\begin{array}{c}\text { Eye, } \\
0.3 \mathrm{~cm}\end{array}$ & $\begin{array}{c}\text { Skin, } \\
0.01 \mathrm{~cm}\end{array}$ \\
\hline 30 days & $\mathrm{C}_{25}$ & 100 & 150 \\
Annual & 50 & 200 & 300 \\
Career & 200 to 400 & 400 & 600 \\
\hline ancludes both uncontrolled and controlled \\
radiation sources with current 5 REM guideline \\
for controlled sources. \\
Preliminary considerations of NCRP scientific \\
committee number 75 on guidance on radiation \\
received in space activities. \\
Can be raised to 50 REM for exploratory missions.
\end{tabular}


TABLE VII. - EFFECTIVE NEUTRON AND GAMMA RAY ATTENUATION

COEFFICIENTS FOR PLANETARY SURFACE MATERIAL ${ }^{\mathbf{a}}$

\begin{tabular}{|c|c|c|}
\hline Soil type & $\begin{array}{c}\text { Neutron attenuatign } \\
\text { coefficient, cm }\end{array}$ & $\begin{array}{c}\text { Gamma ray attenuatjonc } \\
\text { coefficient, } \mathrm{cm}^{-}\end{array}$ \\
\hline $\begin{array}{c}\text { Lunar } \\
\text { Mare basalts } \\
\text { Highland rock }\end{array}$ & 0.0305 & 0.0392 \\
$\begin{array}{c}\text { Mars } \\
\text { Viking 1 site }\end{array}$ & .0325 & .0392 \\
\end{tabular}

aSoil density $1.2 \mathrm{~g} / \mathrm{cc}$.

Watt fission spectrum.

$\mathrm{C}_{2} \mathrm{MeV}$ gammas.

TABLE VIII. - MARTIAN SOIL

\begin{tabular}{|l|c|}
\hline \multicolumn{2}{|c|}{ COMPOSITION $^{\text {El }}$} \\
\hline \multicolumn{1}{|c|}{ Element } & Percent \\
\hline Oxygen & 50 \\
Silicon & 21 \\
Iron & 13 \\
Magnesium & 5 \\
Aluminum & 3 \\
Sulfur & 3 \\
Chlorine & 1 \\
Titanium & 0.5 \\
Potassium & 0.2 \\
Yttrium & 70 ppm \\
Strontium & 60 \\
Rubidium & 30 \\
Zirconium & 30 \\
\hline a Based on Mars Viking \\
Lander site data den- \\
sity of 1.6 g/cc ${ }^{3}$.
\end{tabular}

TABLE IX. - PLANETARY SURFACE RADIOACTIVITY ANALYSIS

\begin{tabular}{|c|c|c|c|c|c|c|}
\hline \multicolumn{2}{|c|}{ Radionuclide } & \multicolumn{5}{|c|}{ Activation in curies at time after shutdown ${ }^{2}$} \\
\hline & & 0.3 days & 100 days & 400 days & 10 years & 80 years \\
\hline $\begin{array}{l}\text { Phosphorous } \\
\text { Aluminum } \\
\text { Magnesium } \\
\text { Iron } \\
\text { Manganese } \\
\text { Silicon } \\
\text { Argon } \\
\text { Manganese } \\
\text { Sodium } \\
\text { All others }\end{array}$ & $\begin{array}{l}-32 \\
-28 \\
-27 \\
-55 \\
-54 \\
-31 \\
-37 \\
-56 \\
-24\end{array}$ & $\begin{array}{c}8.6 \\
361 \\
118 \\
0 \\
0.1 \\
74.1 \\
0.3 \\
32.4 \\
7.7 \\
38.8\end{array}$ & $\begin{array}{r}587 \\
361 \\
118 \\
7.9 \\
21.9 \\
87.1 \\
43.4 \\
37.9 \\
27.4 \\
34.2\end{array}$ & $\begin{array}{l}592 \\
361 \\
118 \\
28.3 \\
62.0 \\
87.1 \\
50.3 \\
37.9 \\
27.4 \\
92.0\end{array}$ & $\begin{array}{l}592 \\
361 \\
118 \\
104 \\
103 \\
87.1 \\
50.3 \\
37.9 \\
27.4 \\
95.3\end{array}$ & 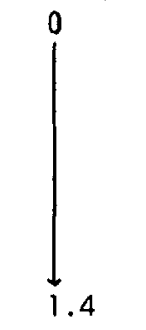 \\
\hline \multicolumn{2}{|c|}{ Total } & 641 & 1325 & 1456 & 1576 & 1.4 \\
\hline
\end{tabular}

after reactor operation at $500 \mathrm{kWt}$ for 10 years. 
TABLE X. - PLANETARY SURFACE SOIL ACTIVATION DOSE RATE ANALYSIS ${ }^{a}$

\begin{tabular}{|c|c|c|c|c|}
\hline \multirow[t]{2}{*}{$\begin{array}{l}\text { Photon } \\
\text { energy, } \\
\text { MeV }\end{array}$} & \multirow[t]{2}{*}{$\begin{array}{l}\text { Maximum } \\
\text { energy } \\
\text { rate, } \\
\text { MeV/sec }\end{array}$} & \multicolumn{2}{|c|}{$\begin{array}{c}\text { Surface activation dose rate } \\
\text { (mREM/hr) at varying distances } \\
\text { from unshielded reactor in a } \\
\text { surface excavation }\end{array}$} & \multirow[t]{2}{*}{$\begin{array}{l}\text { 30-day exposure dose } \\
\text { (mREM) at the back } \\
\text { surface of a } 5-m \text { thick } \\
\text { surface material shielo }\end{array}$} \\
\hline & & $2 m$ & $1 \mathrm{~m}$ & \\
\hline $\begin{array}{l}0.63 \\
1.10 \\
2.75\end{array}$ & $\begin{array}{r}4.36 \times 10^{9} \\
1.42 \times 10^{9} \\
.22 \times 10^{9}\end{array}$ & $\begin{array}{r}0.089 \\
.022 \\
.003\end{array}$ & $\begin{array}{r}17.4 \\
4.4 \\
.6\end{array}$ & $\begin{array}{r}0.82 \times 10^{-3} \\
.21 \times 10^{-3} \\
.03 \times 10^{-3}\end{array}$ \\
\hline Total & $6.00 \times 10^{9}$ & 0.114 & 22.4 & $1.06 \times 10^{-3}$ \\
\hline
\end{tabular}

after shutdown of a $500 \mathrm{kWt}$ reactor operating for 10 years.

baximum energy rate constant from 1 to 10 years after shutdown.

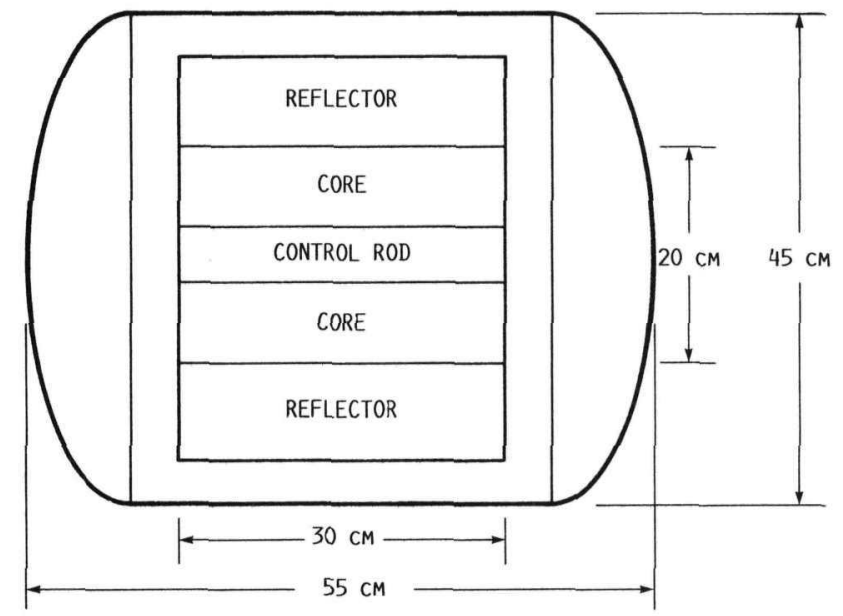

FIGURE 1. - TYPICAL SMALL REACTOR DIMENSIONS.
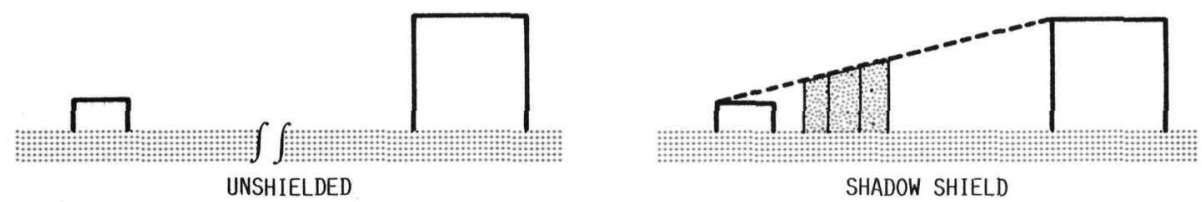

SHADOW SHIELD
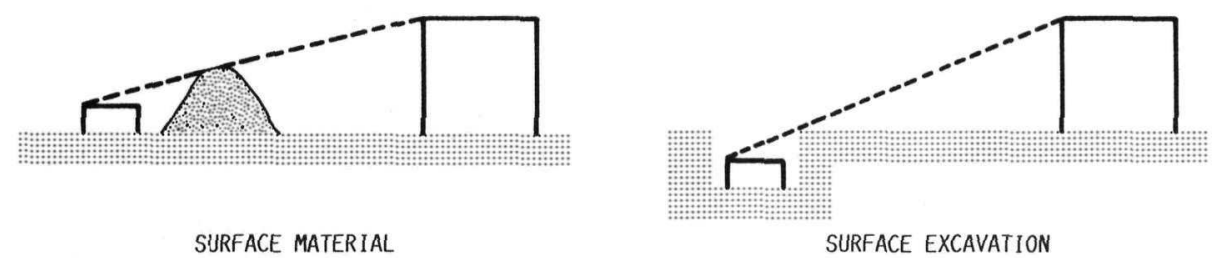

SURFACE MATERIAL

SURFACE EXCAVATION

FIGURE 2. - SHIELDING OPTIONS FOR REACTOR SURFACE POWER. 


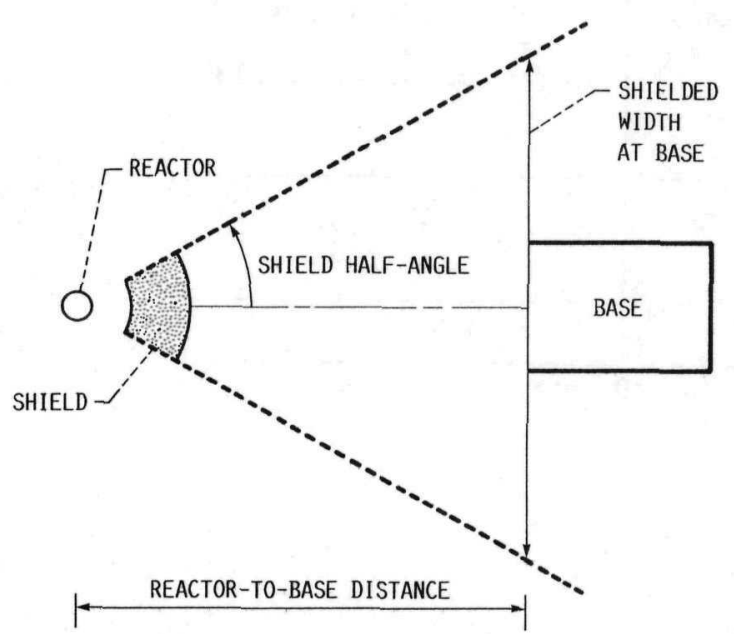

FIGURE 3. - SHADOW SHIELD FOR REACTOR SURFACE POWER.

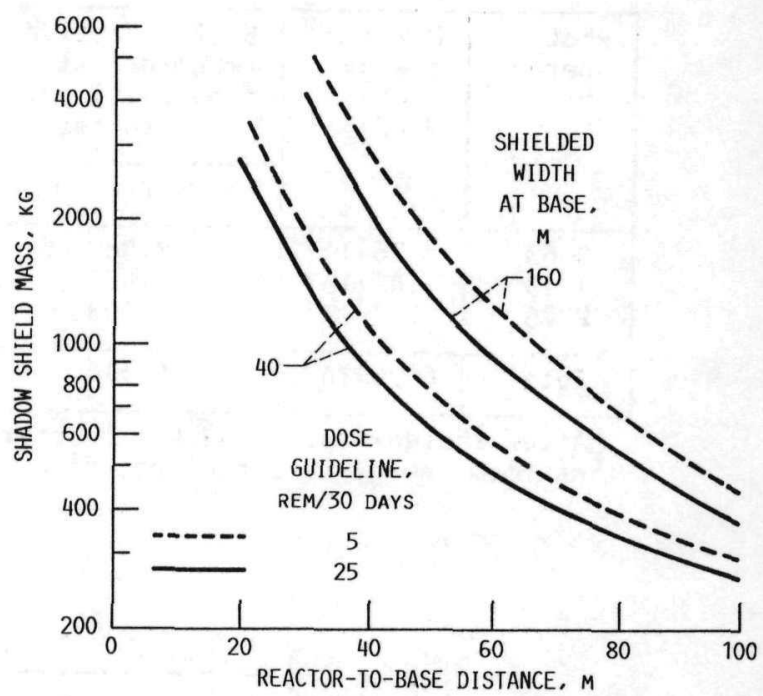

FIGURE 4. - NUCLEAR REACTOR SURFACE POWER SHADOW SHIELD. REACTOR THERMAL POWER, $500 \mathrm{kWT}$; BASE HEIGHT, $5 \mathrm{M}$.

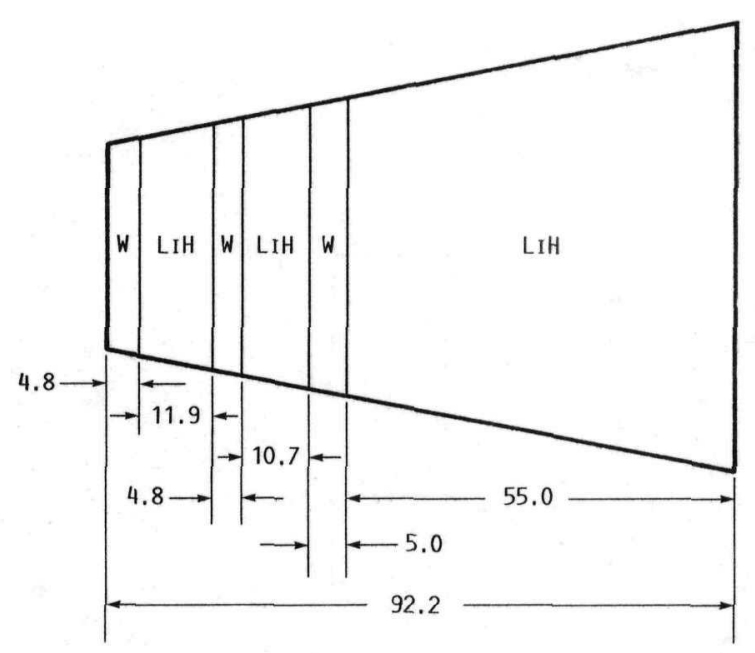

FIGURE 5. - TYPICAL MAN-RATED SHIELD DIMENSIONS. MEASUREMENTS ARE IN CENTIMETERS.

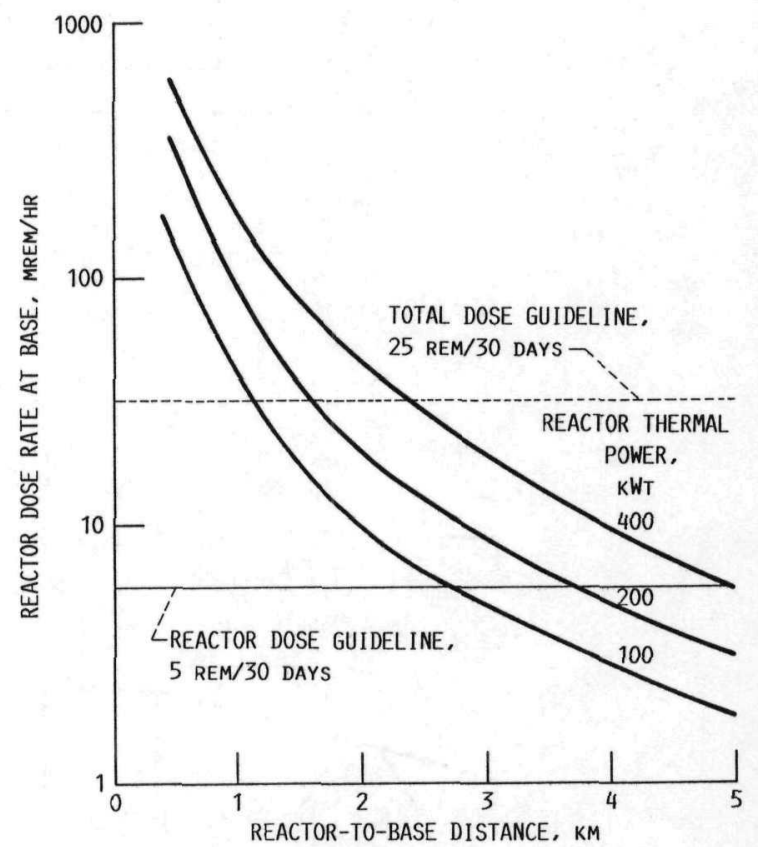

FIGURE 6. - NUCLEAR REACTOR SURFACE POWER UNSHIELDED OPTION. 


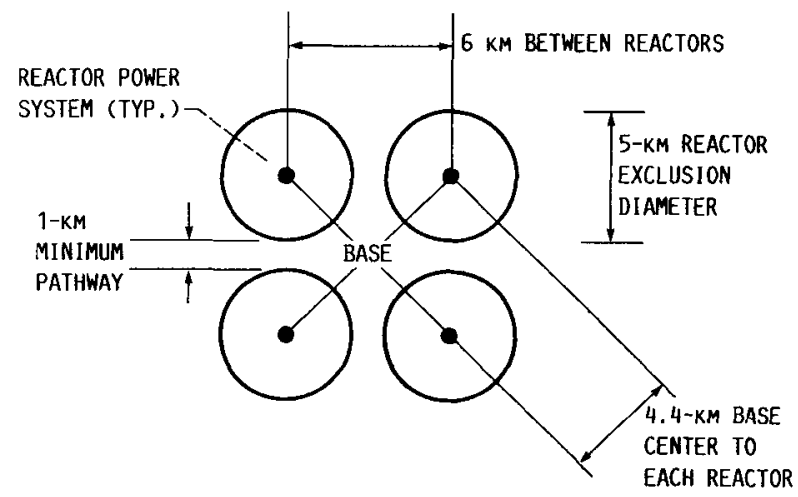

FIGURE 7. - UNSHIELDED REACTOR POWERED SURFACE BASE MODULAR BUILDUP CONCEPT.

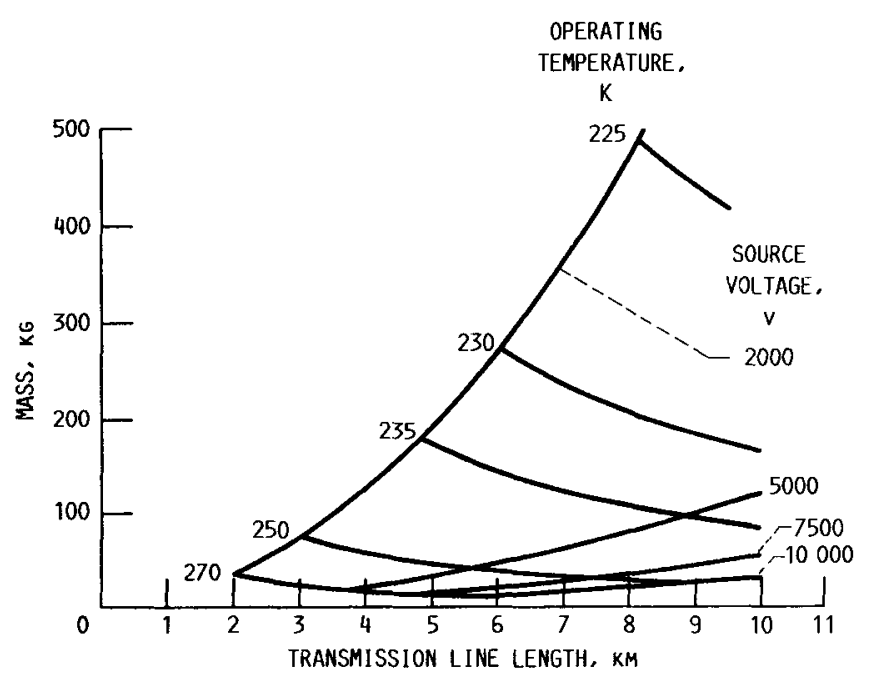

FIGURE 8. - MASS VERSUS LINE LENGTH FOR A DC TRANSMISSION LINE. NONINSULATED SOLID ALUMINUM CONDUCTOR.

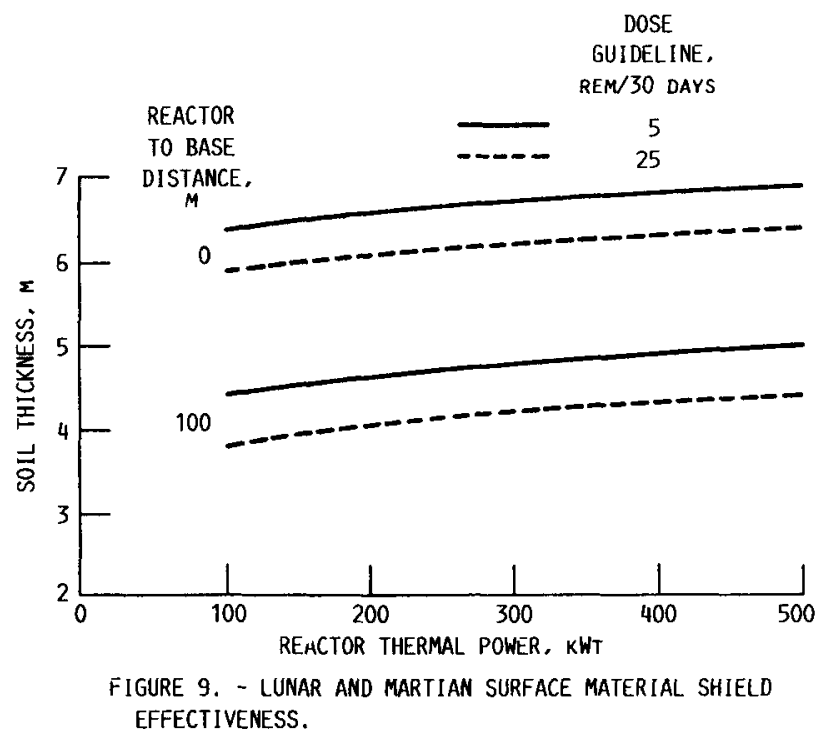




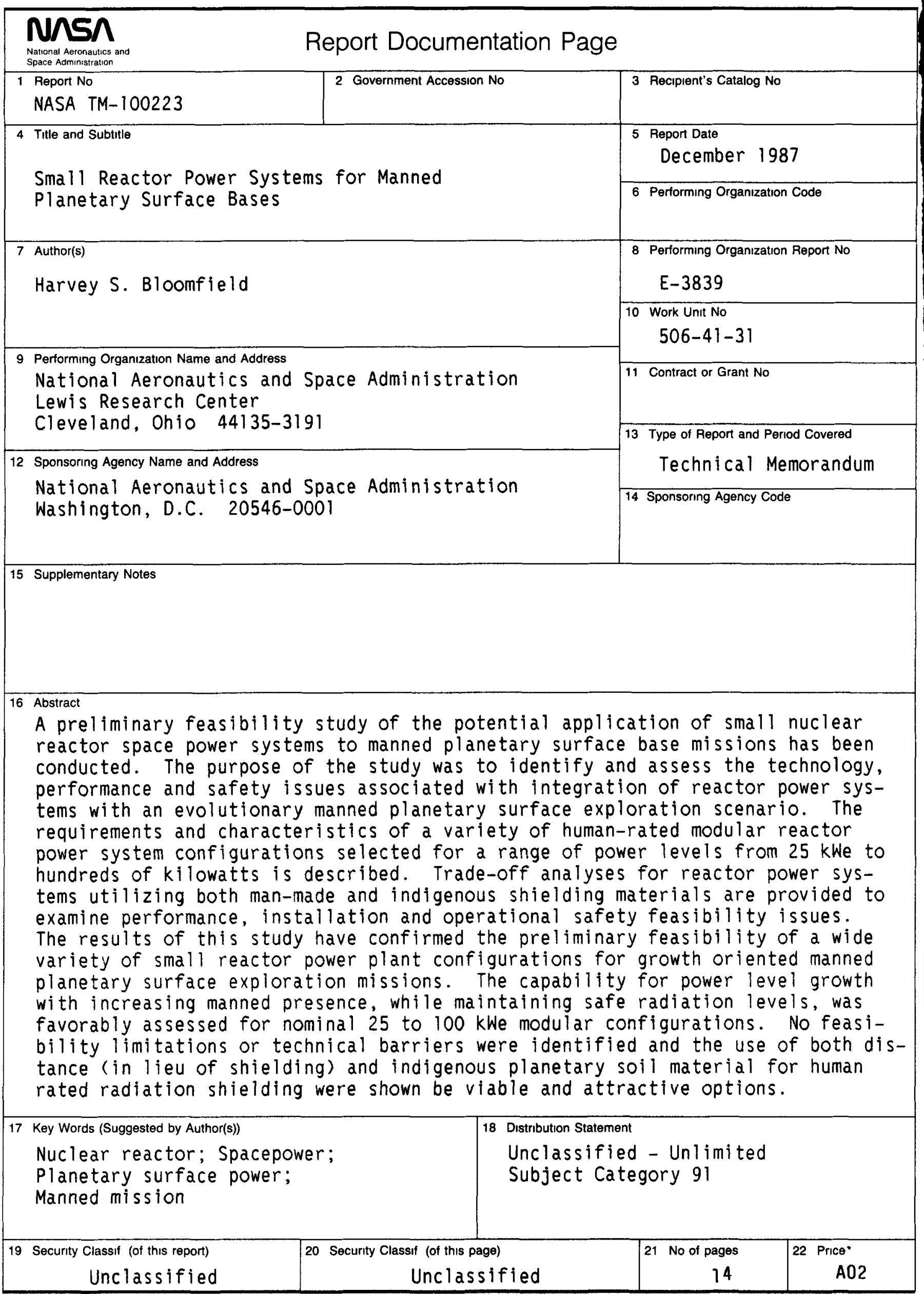

